\title{
GetValue for Windows - Graph Digitizer Equipped with Electrochemical Analyzer
}

\author{
Hidenobu SHIROISHI ${ }^{\text {** }}$, Yuuki KABURAGI ${ }^{\mathrm{a}}$, Michiko SEO $^{\mathrm{a}}$, \\ Sumio TOKITA ${ }^{\mathrm{b}}$ and Masao KANEKO ${ }^{\mathrm{a}}$ \\ ${ }^{a}$ Faculty of Science, Ibaraki University, Bunkyo 2-1-1, Mito, Ibaraki 310-8512, Japan \\ ${ }^{\mathrm{b}}$ Faculty of Engineering, Saitama University, Saitama, Saitama 338-8570, Japan \\ *e-mail: cpx26485@mopera.ne.jp
}

(Received: June 15, 2001; Accepted for publication: July 19, 2001; Published on Web: January 7, 2002)

The graph digitizer "GetValue" which assists in electrochemical analysis was programmed in Visual Basic language. The program has two subroutines of electrochemical analyses. One is for the estimation of diffusion coefficient using Cottrell's equation. The other is for the battery analysis using the plot of current vs. voltage. After digitizing a chart, the user can analyze obtained data by each method. The program can also be used as the standard graph digitizer that assists in obtaining numerical data from a chart on paper. A function that makes two specific points horizontal is equipped with the program to correct the inclination of the image. Specified points can be obtained in seven series. Numerical data are displayed in a table, and can be transferred to the clipboard. Either specified or interpolated methods can be selected, which enabled the efficient obtaining of numerical data.

Keywords: GetValue, Graph digitizer, Electrochemical analyzer, Visual Basic

\section{Introduction}

The rapid progress of a personal computer has reduced its price. In recent years, one out of five people in Japan has a computer. A research laboratory enjoys the merit of the low price. Most instruments for laboratories are now operated by computer, and the measured data can be transferred to another software.

Needless to say, it is important for an instrument to have a function that enables transfer of the numerical data to another software since the obtained data should often be analyzed by equations and compared to another series of data. However, it is not easy for most laboratories in universities and colleges to exchange old instruments for new ones because of a financial problem, so that old instruments and new ones will intermingle in the laboratory for the time being.

Troublesome procedures are needed - the numerical data have to be read out with a ruler on a chart, and inputted into the computer - for a user to use the data recorded on a chart paper for analysis by equations or to draw a chart (figure) together with another series of data. It also requires the same procedures to use the data drawn from articles and reference books for comparison with the experimental data obtained in one's own laboratory. There are some commercial packages for these purposes: Digimatic [1] and Fexitrace [2], and shareware: TechDig [3] and DataThief II [4]. It is useful to incorporate the analysis subroutine for a specific use into this kind of programs.

In the present report, we have made a graph digitizer named "GetValue" which assists in electrochemical analyses. The program has been written in Visual Basic, and runs on the computer with Windows 95, 98, Me and 2000.

\section{Implementation}

We used a PC-9821 machine (NEC) in which Microsoft Windows 2000 was installed for developing "GetValue" with the Microsoft Visual Basic version 6(SP3). The program was tested with Windows 95, 98, Me and 2000 installed in IBM/PC-AT Compatibles.

\section{Usage}

This program has been written using information on the web and some books about Visual Basic [5-8]. Figure 
1 shows a screen shot of "GetValue". A series of procedures to obtain numerical values is shown below. The left button on the mouse is used for a click in the following explanation unless the clicking side is specified. The buttons for magnification (Figure 1(a)) or reduction (Figure $1(\mathrm{~b}))$ are available in each procedure.

1. Loading the image file

First, a chart image is inputted into to a computer with a scanner by using another program that a user usually employs for inputting the image. The image must be saved as "bmp" or "jpg" format. After "GetValue" is started, the image file is loaded by choosing [File] $\rightarrow$ [Open] menu. The image can also be brought to this program from clipboard using [Edit] $\rightarrow$ [Paste picture] menu.

\section{Adjustment of an inclined image}

The "Image rotation button" (Figure 1(e)) enables the adjustment of the angle of the image. Two data points must be specified from the left side on the line that you make horizontal. These points can be moved by dragging. After specifying two data points, click the "execute" button to rotate the image. A progress bar shows how much the process passed.

\section{Setting of a reference frame}

Next, setting of a reference frame is needed for the measurement. Either of the two methods shown below could be selected.

\section{(a) Specification of two points on the image}

After selecting the "Specification of two data point button" (Figure 1(c)), click on the image to specify two data points in the order: upper left and lower right. After clicking, these points can be moved by dragging. Input coordinates after the coordinate transformation. The user can save the parameters by clicking on the "Save settings" button.

(b) Specification of the dpi of a chart image and a datum point on the image

After clicking on the "Specification of a datum point and dpi button" (Figure 1(d)), click on the image to specify a datum point. The program allows you to drag the point. Input the parameters for the coordinate transformation: dpi of the image, coordinates of a datum point after the transformation, and values per $1 \mathrm{~cm}$ after the transformation.

4. Acquisition of values on the image

There are two modes to obtain values on the image. A selected series of points is available for the edit. (a) Specific point mode

After selecting the "Point-setting button" (Figure 1(f)), choose a series from an image combo box (Figure 1(h)). Put a point on which you want to obtain a value. The points can be moved by dragging, and erased by clicking on the right button.

(b) Spline mode

After clicking on the "Spline mode button" (Figure $1(\mathrm{~g})$ ), operate this mode like (a). More than four points are needed for calculating the spline curve because of the cubic spline function. The same $x$ value cannot be specified in this mode. For example, when obtaining values on a cyclic voltammogram, another series should be selected at the reverse scan.

5. Display of the numerical values

By clicking on the button for displaying the numerical values (Figure 1(I)), a table is obtained. The data are transferred to the clipboard by selecting a copy menu.

6. Analyses of data

(a) Linear least-square method

The data can be analyzed by least-square method by [Analysis] $\rightarrow$ [Least Square] menu.

(b) Estimation of diffusion coefficient

Figure 2 shows the window of Cottrell's equation analysis. The analysis can be used by [Analysis] $\rightarrow$ [Cottrell's equation] menu. The user must input the parameters : y scale, concentration, and the number of electrons $(n)$. The diffusion coefficients are calculated by [Calculation] button.

(c) Battery analysis

Figure 3 shows the window of battery analysis. The user can obtain parameters such as open-circuit voltage, short-circuit current, and fill factor.

\section{Agreements for using the pro- gram}

The "GetValue" is freeware. We cannot be responsible for damages that you might receive when using this program. Please feel free to contact us when you find bugs. We are also waiting for suggestions to improve the program. The program can be downloaded not only at the CSJ ftp server but also at the following address.

http://klab01.sci.ibaraki.ac.jp/ Kanekolab/ 


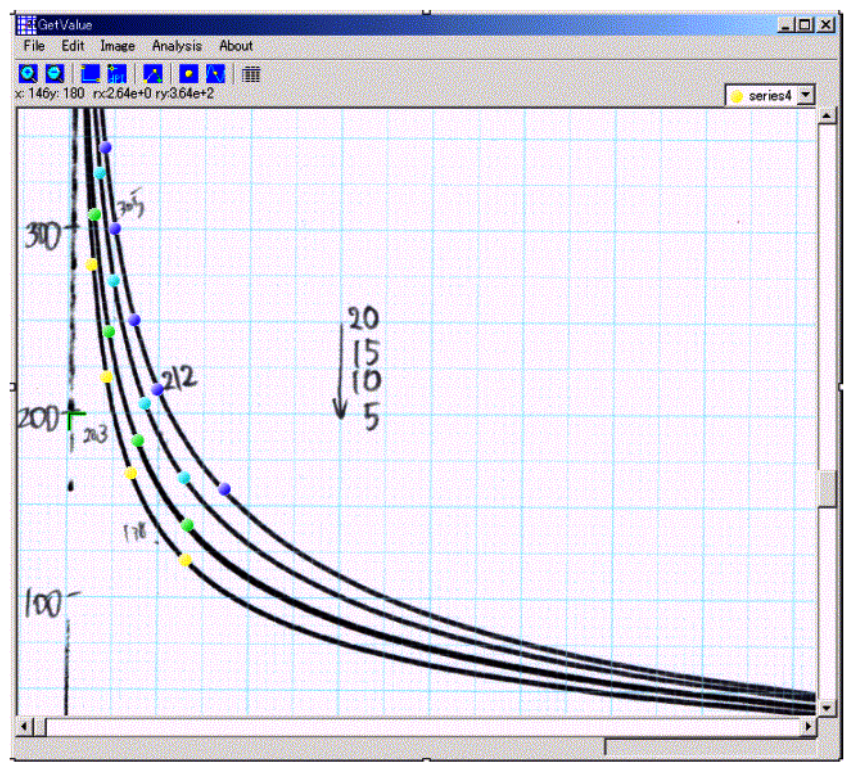

$\Phi$

(a) magnification button

3

(b) reduction button

(c) two data point button

APT

(d) a datum point and dpi button

$\triangle$ (e) Image rotation button

- (f) Point-setting button

(g) Spline mode button

(h) displaying the numerical values

Figure 1. Screen shots of "GetValue"

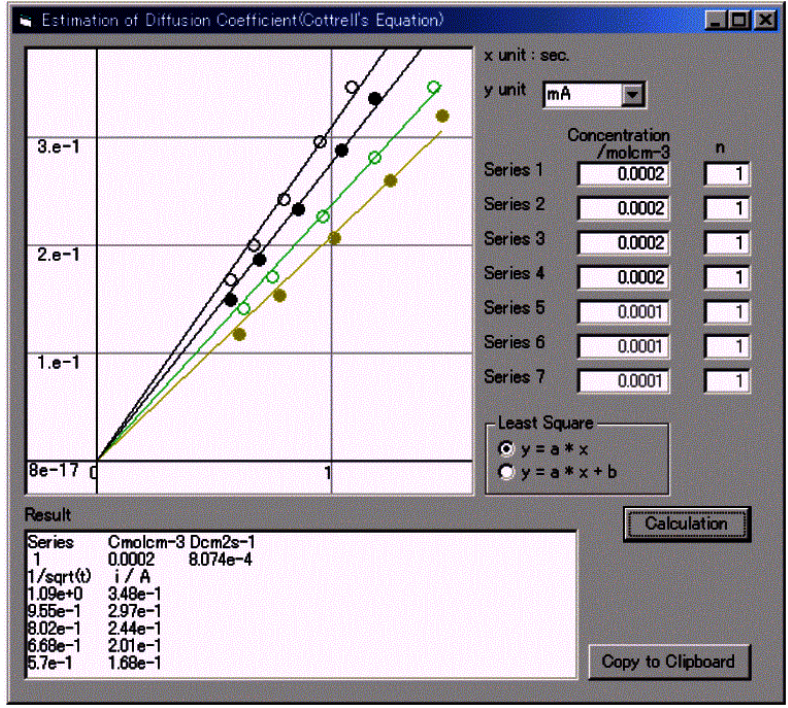

Figure 2. Estimation of Diffusion coefficients using Cottrell's equation.

The authors acknowledge a Grant-in-Aid for JAERI's Nuclear Research Promotion Program (JANP) from Japan Atomic Energy Research Institute.

\section{References}

[1] http://www.huvard.com/feb/digimatic.html

[2] http://www.treestar.com/flexitrace/

[3] ftp://ring.aist.go.jp/pub/pc/winsite/win3/desktop/ tdig11b.zip

[4] http://www.nikhef.nl/user/keeshu/datathief/index.html

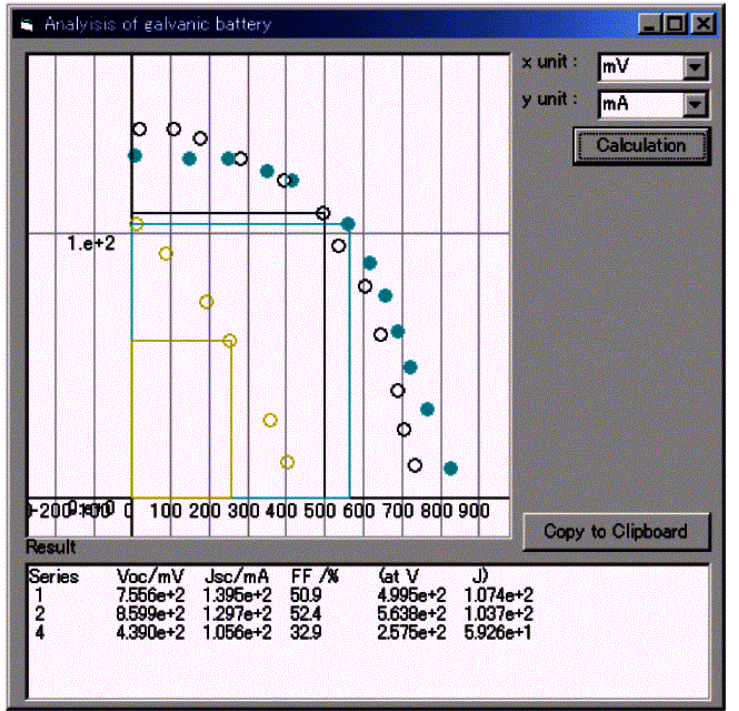

Figure 3. Illustration of battery analysis.

[5] T. Hidaka, Visual Basic Game Programming no ouyou 50 rei-Total technique hen -, Softbank Co. Ltd. (1997).

[6] A. Kawanishi, Visual Basic 5.0 Jyoukyu-hen, Gijyutsu-Hyoron Co. Ltd. (1998).

[7] T. Matsuda, Visual Basic 6.0300 no waza, Galliver Ltd. (1999).

[8] H. Kitayama, Hajimeteno Visual Basic 6.0 Graphics \& Game Programming, Gijyutsu-Hyoron Co. Ltd. (2000). 


\title{
GetValue for Windows -電気化学測定解析を実装し た グラフデジタイザの開発
}

\author{
城石 英伸 ${ }^{\mathrm{a} *}$, 鏑木 悠城 ${ }^{\mathrm{a}}$, 瀬尾 美智子 ${ }^{\mathrm{a}}$, 時田 澄男 $^{\mathrm{b}}$, 金子 正夫 ${ }^{\mathrm{a}}$ \\ $a$ 茨城大学理学部自然機能化学科, $=310-8512$ 茨城県水戶市文京 2-1-1 \\ $\mathrm{b}$ 埼玉大学工学部応用化学科, $\bar{\top} 338-8570$ 埼玉県さいたま市下大久保 255 \\ *e-mail: cpx26485@mopera.ne.jp
}

\begin{abstract}
電気化学測定解析を実装したグラフデジタイザ “GetValue”、Visual Basicを用いて作成した。こ の “GetValue”は、時間-電流曲線から拡散係数を見積もる解析ルーチン (Figure 2) と電流-電位曲線から フィルファクターなどの電池特性を解析するルーチン (Figure 3) を実装しており、数値化直後に、必 要なパラメータを入力するだけで光れ光れの解析が実行できる。また、通常のグラフデジタイザ (用 紙等に記録されたグラフを数值化するソフト) としても使用できる。数值化する際に必要な基準点の 設定は、取り込み解像度 (dpi) と基準点を用いる方法 (ツールバー Figure 1(c)) またはチャート上の 2 点を用いる方法が選択 (ツールバー Figure 1(d)) できる。また、スキャナーで取り込む際に生じる微妙 な角度の曲がりを修正するため、指定した 2 点がフラットになるような回転機能を装備した (ツール バーFigure 1(e))。データは一度に7系列まで分けて取り込むことができる。出力方法として、ポイン 卜した点を数值化する機能 (ツールバー Figure 1(f)) のほかに、スプライン補間による読み取りも装備 し (ツールバーFigure 1(g))、少ない点を指定するだけで効率よくデータを数值化できるようにした。 キーワード : GetValue, Graph digitizer, Electrochemical analyzer, Visual Basic
\end{abstract}

